\title{
THE POWER OF BLOOD: THE MANY FACES OF WOMEN'S MONTHLY MENSES IN JEWISH LAW \& BEYOND
}

PAMELA LAUFER-UKELES*

\section{Intro: The Many Faces of Menstruation}

Menstruation has many faces. This Essay will discuss competing narratives relating to menstruation as portrayed in Jewish law and culture, and assess the implications of such narratives for modern legal systems. These narratives depict menstruation in all its contradictions - as taboo and power, as health and imperfection, and as reflecting biological difference but not inequality. Each narrative will be discussed from a textual, legal, communal and, occasionally, personal perspective, conveying different meanings that have different cultural impacts, modern applications and reflect different aspects of the quest for equality.

Together, these narratives provide a holistic vision of womanhood that resists simplification. Acknowledging that not only women menstruate, in this Essay I refer to women as those who menstruate because this is the category associated with menstruation used in Jewish law and it is the complexity of womanhood revealed by Jewish law and culture that I address. ${ }^{1}$ These four faces of menstruation are not characterized as positive or negative in and of themselves; rather, I analyze them each on their own terms, discussing how they may impact women in both negative and positive ways. The variability of these narratives demonstrates the need for women to shape their own narratives around their bodies in order to empower themselves within their communities. Moreover, the multiplicity of faces that menstruation involves, and the different ways that femininity can therefore impact womanhood, counsels promoting menstrual justice in a variety of ways, and from a variety of perspectives, creatively

\footnotetext{
* Professor of Law and Healthcare Administration, College of Law and Science, Hod Hasharon Israel. B.A., Columbia College, Columbia University; J.D. Harvard Law School. I would like to thank my research assistant Gabrielle Agus and the staff of the Columbia Journal of Gender and Law for invaluable help in preparing this article for publication. Thank you also to the Symposium Organizers for bringing this important project to fruition.

${ }^{1}$ Because I am reflecting on Jewish law, which uses binary concepts of man and woman, I will refer to "woman" but do so with sensitivity to the reality that many experience gender as non-binary and fluid and that some people who are biologically female identify as male and vice versa. All persons affected by menstruation are affected by the different aspects of menstruation I discuss.
} 
empowering women by recognizing their individual complexity. In Jewish law, menstruation engenders impurity, authority, fertility, and biological difference, and each of these faces of womanhood will be discussed in turn.

\section{Blood as Stain and Impurity}

In Jewish law, the primary face of menstruation is impurity. When a woman menstruates, discharging blood from the vagina, Jewish law, in at times uncomfortably technical and unscientific ways, decrees that she is "niddah." Niddah means "separation" and is used to describe ritual impurity. ${ }^{2}$ The law instructs that vaginal blood can contaminate and desecrate; thus, during her menstruating and seven days thereafter, a woman must separate from her husband, and historically refrain from other sacred rituals until she purifies herself by immersing in a ritual bath. ${ }^{3}$

In other instances the concept of niddah is associated with sexual deviance and idolatry. ${ }^{4}$ It is also understood to connote "sickness" according to Rabbinic authorities or a curse according to the Babylonian Talmud. ${ }^{5}$ Not all blood contaminates under Jewish law, just menstrual blood. ${ }^{6}$ A man who lays with his wife during niddah is punishable by excommunication (karet). ${ }^{7}$ Indeed, to ensure that men keep away from menstrual blood, some Rabbinical sources suggested that conceiving a child with a woman who is niddah

\footnotetext{
${ }^{2}$ The Hebrew term used for menstruation in Leviticus 15:19, 20, 24, 33 is niddah, which has as its root "ndh," meaning "separation," required due to ritual impurity,

${ }^{3}$ Tur Shulchan Aruckh, Yoreh De'ah 183:1; 188:4; According to Leviticus, touching a menstruating woman yielded impurity until sunset; Sefer Hachinuch 182, 166.; Tur Shulchan ARUCKH, Yoreh De'ah 183:1. See also Kalman Kahana, Daughter of Israel Laws of Family Purity (1973) (complete guide to the laws of Niddah).

${ }^{4}$ Ezekial 7:19; Lamentations 1:17; Ezra 9:12 (using niddah to refer to ritual impurity).

${ }^{5}$ Ibn Ezra Commentary on Leviticus 20-:18 (referring to niddah as illness); Maimonides, MishnAH TORAH, ISUREI BIAH (prohibitions on sex) ch. 4: 21 (referring to niddah as a sickness); Eruvin 100b (BABYLONIAN TALMUD).

${ }^{6}$ Maimonides, Mishnah Torah, ISUREI BIAH (prohibitions on sex) 5:5, 6 .

${ }^{7}$ Tirzah Meachem, An Abbreviated History of the Development of the Jewish Menstrual Laws, in Women AND WATER, 23, 24 (Rachel Wasserfall, Ed. 1999) (hereinafter, "Women and Water").
} 
will spiritually pollute him and his offspring thereafter by rendering the child illegitimate (mamzer). ${ }^{8}$

This characterization of natural female biological processes as defiling can be experienced as rejection and degradation. ${ }^{9}$ Indeed, I had a female Jewish law instructor, considered widely to be a great scholar, who studied these laws in such detail that she could not contemplate marriage. She explained that she would not subject herself to purification rituals because of her body's natural (and life-giving) processes. However, she would also not put a man in the position of needing to break the law in order to touch his wife. In fact, the perceived unfairness of these laws' treatment of the female body became so overwhelming to her that she left the study of Jewish law entirely.

Other Jewish law scholars try to distance themselves from such desecrating symbolism, focusing on the more technical aspects of the process of women's purity rituals, ${ }^{10}$ comparing them to impurity resulting from the spilled seed from ejaculation outside of sex. ${ }^{11}$ Ritual acts that separate times of the month need not necessarily imply illness or subordinate women, despite semantics. Indeed, many religious couples find the constant renewal after times of separation refreshing and beneficial to their relationships.

While this perspective may seem remote, it is also still relevant. Blood physically sullies the body in real and messy ways. Although we might have a sense of when it is expected, the menses exact arrival comes as a surprise each month. ${ }^{12}$ Studies demonstrate that menstrual "leaks" are common in every menstrual cycle, ${ }^{13}$ resulting in lack of preparation with necessary products, causing absence from various educational and

\footnotetext{
${ }^{8}$ Shaye J.D. Cohen, Purity, Piety, and Polemic: Medieval Rabbinic Denunciations of "Incorrect" Purification Practices, in WOMEN AND WATER 82, 85.

${ }^{9}$ See e.g., Howard Eilberg-Schwartz, The Savage In Judaism (1990); Paula Hyman, The Other Half: Women in the Jewish Tradition, in THE JEWISH WOMAN 110-112 (E. Koltun ed. 1976).

${ }^{10}$ Norman Lamm, A Hedge of Roses 40 (1966).

${ }^{11}$ Meachem, supra note 77, at 24-25.

${ }^{12}$ Daily temperature checks can provide more clarity, but such careful charting is rare in modern times, unless a woman is closely tracking her fertility in order to conceive. See generally TONI WESCHLER, TAKING Charge OF Your Fertility (2015).

${ }^{13}$ Allison Sadlier, Should Feminine Hygiene Products be Free? NY Post (December 3, 2019), https://nypost.com/2019/12/03/should-feminine-hygiene-products-be-free/) [https://perma.cc/EQF4-HJNW].
} 
professional functions. ${ }^{14}$ Therefore, those who menstruate may experience panic and unsightly stains in public, creating the potential for embarrassment and shame every month.

In this regard, the laws of the workplace and public spaces abandon women in a manner that reinforces menstruation as sickness. Tampons and pads are rarely available, even for purchase, in public facilities. Since menstruation is a regular concern for over fifty percent of the population, this reality is difficult to explain. Toilet paper is free and accessible, why are sanitary napkins different? ${ }^{15}$ The intuitive explanation is that blood, or any sign of it, is better hidden. Similar to disgust towards public breastfeeding, there is a distaste for public allusions to menstruation. ${ }^{16}$

Moreover, sanitary products are not cheap. ${ }^{17}$ Women living below or near the poverty line often struggle to access products allowing them to maintain regular life during menstruation. Only a few states obligate public high schools to provide sanitary products in bathrooms. ${ }^{18}$ New York has banned taxes on such products. ${ }^{19}$ And one, singular town in Massachusetts, requires the free public dissemination of tampons and napkins. ${ }^{20}$ Some states mandate providing menstrual products in correctional facilities and shelters, but the

\footnotetext{
${ }^{14} I d$.

${ }^{15} \mathrm{Id}$.

${ }^{16}$ Emily Peck, Free Tampons Should be a Human Right, Huffington Post (March 8, 2016), https://www.huffpost.com/entry/free-tampons-human-right_n_56deffbce4b03a40567ale33 [https://perma.cc/FLR2-SX22].

${ }^{17}$ Awareness about "period poverty" is growing. See e.g., Margaret E. Johnson et. al., Title IX \& Menstruation, 43 HARV. J. L. \& GENDER 225, 252 (2020).
}

${ }^{18}$ Id. at 255- 56 (Showing that only New York, New Hampshire, Illinois, California, and Georgia obligate public high schools to provide sanitary products in bathrooms).

${ }^{19}$ Abigail Jones, New York Terminates the Tampon Tax, NewsweEk (July 21, 2016), https://www.newsweek.com/new-york-tampon-tax-cuomo-periods-tampons-menstruation-donald-trump482918) [https://perma.cc/8HP2-YMFE] (showing many states still have such a tax).

${ }^{20}$ Mass Town to be the First in the U.S. to Require Tampons in Public Bathrooms, CleanLinK, https://www.cleanlink.com/news/article/Mass-Town-To-Be-First-In-US-To-Require-Tampons-In-PublicBathrooms--23955 [https://perma.cc/W88Y-VXCK]. 
majority do not, posing enormous expenses on poor and captive women. ${ }^{21}$ It is surprising that these services are so rare and recent, reflecting the hidden nature of these problems.

Even the name "sanitary products" signals uncleanliness. The filth translates to a sort of "shame" and culpability that a woman should just deal with, without expecting accommodations.

\section{Menses as Sexual Authority}

Having started with the most potentially demeaning face of menstruation, next I explore the power of menstruation to empower. After hearing me speak about the limited role of women in public prayer and the plight of women who are chained wives (agunot), a fellow follower of the Jewish laws of impurity said to me, "But how about mikveh (ritual bathhouses)? That is where women have all the power!"

For women who accept the dictates of Jewish law, the flipside of being required to separate until purification, is that only a woman can make herself, and her body, available to her husband. Women determine when the days of menstruation (and then seven clean days) have passed allowing for purification, placing a great responsibility on women in a system of Jewish laws in which most commandments are placed on men. Many Jewish women who practice the laws of ritual purity find this authority empowering. ${ }^{22}$ In Jewish culture, women are, essentially, the arbiters of sex..$^{23}$ Although such intimate negotiations are overwhelmingly secretive, research demonstrates that such power is wielded by women who use this authority in determining when to purify to avoid sexual relations when unwanted..$^{24}$ Being the responsible party for when the sexual act is permissible, gives women power in orchestrating sexuality, a context in which men are often perceived as dominant. ${ }^{25}$ Relationships are complicated, and resisting sex can create

\footnotetext{
${ }^{21}$ Margaret E. Johnson, Menstrual Justice, 53 U.C. DAvis L. REv. 1, 59 (2019).

${ }^{22}$ Tova Hartman \& Naomi Marmon, Lived regulations, systemic attributions: Menstrual Separation and Ritual Immersion in the Experience of Orthodox Jewish women, 18(3) GENDER \& SOC'Y, 389, 397-99 (2004).

${ }^{23} I d$. at 399. I only refer in this Essay to heterosexual sex because this is the sex governed by Jewish law.

${ }^{24}$ Id.; Nathalie Zemon Davis, Women ON THE MARgins (1995); Rachel Wasserfall, Bargaining for Gender Identity 29(4) ETHNOLOGY 327-40 (1990).

${ }^{25}$ Diane Richardson, Sexuality and Male Dominance, in InTRODUCING WOMEN's Studies 74, 74 (1993) ("Most feminists would agree that men's power over women, economically and socially, affects sexual relationships;
} 
hostility and discord. Therefore, under Jewish law, women may feel empowered by their ability dictate the timing of the sexual encounter when it is most welcomed and on their own terms. ${ }^{26}$

There is an assumption that a woman wants to be able to touch her husband, and therefore will rush "to be purified." 27 Jewish law further assumes that a woman's power lies in making herself desirable to her husband. ${ }^{28}$ Moreover, this power to determine readiness for purification can result in women being pressured to use the mikveh in order to make themselves available for sex. Indeed, during the coronavirus pandemic, some women announced that they would not immerse for fear of contagion in public baths, ${ }^{29}$ but there was pressure to keep mikvehs open despite the closure of schools and synagogues. ${ }^{30}$ Furthermore, when questions arise regarding whether menstruation has sufficiently ceased (stains that can be a sign that she is not ready to purify), Jewish law instructs a woman who is unsure about her niddah status to consult with a (male) Rabbinical figure. Shifting authority from a woman's control to Rabbinical control creates pressure and may undermine her sense of dignity, ${ }^{31}$ making her feel complicit in her own subordination. Many women therefore choose to make these determinations on their own. ${ }^{32}$

Despite such pressures, the implicit power wielded by women under Jewish law to convey readiness for sex can be instructive in modern law. The restriction on sex breaks the dichotomy between consent and refusal by adding a spiritual element to the

generally speaking, women have less control in sexual encounters than do their male partners, and are subjected to a double standard of sexual conduct which favours men.").

${ }^{26}$ Hartman \& Marmon, supra note 21, at 400.

${ }^{27}$ Niddah 31b (BABYLONIAN TALMUD).

${ }^{28} I d$.

${ }^{29}$ Kelsey Ogood, Is the Mikveh Safe from Covid-10, FORWARD (March 29, 2020), https://forward.com/life/442617/is-the-mikveh-safe-from-covid-19-some-women-opt-for-the-ocean/ [https://perma.cc/GB8H-VFDL].

${ }^{30}$ Sam Sokol, Women's Ritual Baths Remain Open, TimES OF IsRAel (March 31, 2020), https://www.timesofisrael.com/womens-ritual-baths-remain-open-during-pandemic-but-fail-to-wash-awayfears/ [https://perma.cc/BGE9-7WC6].

${ }^{31}$ Hartman \& Marmon, supra note 21, at 396.

${ }^{32}$ Id. at 397. 
conversation. Robin West has argued that sexual relations should not just be subject to consent, but should also be wanted; autonomy is not sufficient, rather, conditions for desire must be in place to facilitate an invited sexual encounter. ${ }^{33}$ West argues that even consensual sex, if unwanted, can cause various harms. ${ }^{34}$ Thus, West advocates for promoting conditions that facilitate sex that is "welcomed" and not merely consented to. ${ }^{35}$ Requiring women to act affirmatively to purify, and then relate their readiness to their husbands, may facilitate more invited and welcomed sexual relations. In the context of secular law, more can be done to facilitate welcomed sexual encounters by improving the conditions under which consent is given and by more broadly promoting equality substantively, without overreliance on the sufficiency of liberal accounts of consent. In the context of ongoing inequality and social pressures, and the general complexity of relationships, although lack of consent may be used to demarcate assault, consent is not always sufficient demarcation for promoting beneficial sexual encounters. To avoid confrontations and hostility, women may feel pressured to consent to unwanted sex, which can still be harmful to them. Sexual harassment, especially in the \#MeToo era, instructs that the space between coercion and consent is often not sufficient to protect women in the face of weighty power imbalance and societal pressure; women too often consent even when the sexual encounter is not desired. Thus, reflecting the reality of compromised autonomy and complex social relationships, Jewish law provides insight into creating conditions that facilitate sexual encounters that are not just consensual, but also invited.

\section{Fertility as Purpose and Determinism}

We now shift from the potentially empowering underside of menstruation to its pragmatic side. The act of having one's period signals fertility and the ability to create life, which is the most valued commandment in Jewish law. Indeed, Talmudic scholars emphasize this connection, explaining that when a woman has menstrual blood she is

\footnotetext{
${ }^{33}$ Robin West, Sex, Law and Consent, in The Ethics of Consent 221, 224 (Miller \& Wertheimer 2010).

${ }^{34} I d$. at 233.

${ }^{35} I d$. at 243.
} 
fertile; when she does not, she has lost her fertility. ${ }^{36}$ Rabbis have even opined that the more menstrual blood, the more fertile. ${ }^{37}$

The commandment to reproduce is imperative upon men under Jewish law, at the very least requiring one child, but usually deemed necessary to have two children. ${ }^{38}$ According to Jewish law, a man should not marry an infertile women unless he already has children with another woman..$^{39}$ And, ultimately, if a man unknowingly marries an infertile woman, he can divorce her without paying her the ketubah (contractual bride price) agreed to before the marriage and intended to sustain her upon divorce until she can find an alternative source of income. ${ }^{40}$ This is the case even if the woman did not commit fraud or have reason to know she was infertile. Moreover, since polygamy has been outlawed under Jewish law, a man is supposed to divorce his wife if she cannot bear him children. ${ }^{41}$

Such divorce laws, which are still potentially relevant today in Israeli divorce, incorporate Jewish law and centralize fertility in women's lives. This emphasis on procreation has mobilized Israel to be a pioneer in alternative reproductive techniques, including surrogate motherhood, because the alternative is the need for a divorce. ${ }^{42}$

\footnotetext{
36 "R. Yehuda says: 'Every vine [woman] has wine [menstrual and virginal blood] within her. But one which does not have wine [menstrual and virginal blood] within her—she is dorqetei [infertile]." MisHNAH, Niddah 9:11.
}

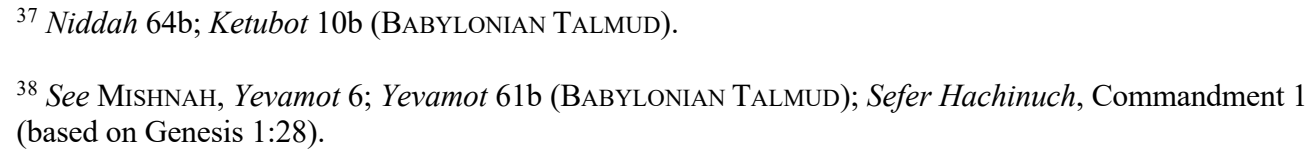

${ }^{37}$ Niddah 64b; Ketubot 10b (BABYlonian TALMUd).

${ }^{38}$ See Mishnah, Yevamot 6; Yevamot 61b (Babylonian Talmud); Sefer Hachinuch, Commandment 1 (based on Genesis 1:28).

${ }^{39}$ Maimonides, Mishnah Torah, Ishot (women)15:7; Maimonides, Mishnah Torah, Issurei Biah (prohibitions on sex) 21:26; TUR SHULCHAN ARUCH, Even Ha'ezer 1:8.

${ }^{40}$ Tur Shulchan ARuch, Even Ha'ezer 117:4.

${ }^{41}$ See Mishnah, Yevamot 6:6 ("No man may abstain from keeping the law "Be fertile and increase" (Genesis 1:28), unless he already has children: according to the School of Shammai, two sons; according to the School of Hillel, a son and a daughter, for it is written, "Male and female He created them" (Genesis 5:2). If he married a woman and lived with her ten years and she bore no child, it is not permitted him to abstain [from fulfilling this legal obligation]."); Pinhas Shifman, New Reproductive Technologies and Jewish Law, 12 Jewish L. AnN. 127, 133-135 (1997); Pinhas Shifman, A Perspective on Surrogate Motherhood in Jewish Law, in Frontiers of Family Law 79 (Andrew Bainham and David S. Pearl Eds. 1993); Pamela LauferUkeles, Gestation; Work for Hire or the Essence of Motherhood? A Comparative Legal Analysis, 9 DuKE J. GENDER L. \& POL'Y 91, 21 (2002).

${ }^{42} I d$. 
Unique among developed countries, Israel's birthrate stands above 3 children per woman across the population. ${ }^{43}$ More money is spent on IVF per capita in Israel than in any other country in the world - enough IVF cycles for birthing two children per couple. ${ }^{44}$ Not having children in Israel is widely perceived as deviant, limiting free choice for women, and making motherhood deterministic. ${ }^{45}$ Israeli law generally emphasizes the importance of motherhood, creating obstacles for women's equality. For instance, exemptions are required for women's military service in the case of marriage or pregnancy, impacting women's equality in Israel as women's service in the army is crucial for professional advancement. ${ }^{46}$

Beyond the borders of Israel, for women who have been ill, undergone chemotherapy or suffer from infertility, the impact of "losing" one's period cannot be overstated. After years of chemotherapy, a friend rejoiced at her period's return. For her, despite its unpleasantness, it signaled wellness and vitality. Culturally, and as a matter of social policy, more can be done to ensure that women feel they have choices and that infertility is not perceived as deviant, needing a cure, or a sign of lost vitality. In the same way that menstruation is hidden, menopause is not sufficiently discussed, and contending with these topics is essential to women's health.

\section{Menstrual Cycles as Differentiation}

Finally, menstrual cycles denote biological differences between men and women. ${ }^{47}$ An extension of menstruation as defilement requiring separation and the practice of relegating women to so-called "menstruation" huts has threatened women's lives, exposing them to extreme weather conditions, animal attacks, and sexual violence,

\footnotetext{
${ }^{43}$ World bank fertility rates point to the number in 2020 as 3.09 in Israel and 3.6 in the West Bank and Gaza. World Bank Group, Fertility rate, total (births per woman) - Israel, West Bank and Gaza,

DATA.WORLDBANK.ORG, https://data.worldbank.org/indicator/SP.DYN.TFRT.IN?locations=IL-PS [https://perma.cc/NWB7-WL6N].

${ }^{44}$ See Daniel Sperling, Commanding the "Be Fruitful and Multiply" Directive: Reproductive Ethics, Law, and Policy in Israel, 19 Cambridge Q. HealthCare Ethics 363-71 (2010).

${ }^{45}$ See e.g., Larissa Rememnick, Childless in the Land of Imperative Motherhood: Stigma and Coping Among Infertile Israeli Women, 43 SEX Role 821, 822-24 (2000).

${ }^{46}$ See Pamela Laufer-Ukeles, Cross-Dressers with Benefits: Female Combat Soldiers in the United States and Israel, 41 U. BALT. L. REV. 321, 343-44 (2012).

${ }^{47}$ The exception is transgender men who menstruate.
} 
causing fatalities and scandals in places like Nepal (Hindu custom). ${ }^{48}$ Indeed, difference and separation - can be threatening as separation often leads to subordination and exclusion. This is an understandable historical fear pointed to by modern critics of feminist movements that seek gender-specific accommodations who fear that recognizing difference leads to determinism and discrimination. Fear of stereotypes have led many women, liberal feminists in particular, to shun accommodations that could promote more substantive equality. ${ }^{49}$

Equal protection law, the primary means of securing equality in the United States, rests on the belief that people who are similarly situated should be treated the same, ${ }^{50}$ helping to secure rights for women and minorities in the workplace. However, when it comes to pregnancy, breastfeeding, issues of stature and size, women fare much worse. As a matter of constitutional law, the United States does not provide paid maternity leave, mandate protection of public breastfeeding, or even guarantee equal opportunity in the military. Menstruation is an unseemly symbol of biological difference, and therefore it is not surprising that it receives no recognition or protection.

But, separation and differentiation does not inevitably lead to debasement. Some women attest to the benefits of separate schooling and cultural practices. Even in the context of separation huts, some women find the respite from their regular, tedious lives desirable, facilitating female bonding and empowerment. ${ }^{51}$ Indeed, ignoring difference also harms women, obscuring the ways laws do not recognize or support women's biological realities. The lack of accommodations for pregnancy and other biological differences can have a significant negative impact on women's professional success and financial wellbeing. If we are really comfortable in our own skin, biological difference must be celebrated, not ignored - pregnancy, breastfeeding, and menstruation are biological triumphs. Women cannot settle for gender neutrality as the only path to empowerment. Instead, like Catherine Mackinnon argues, women should have it both

\footnotetext{
${ }^{48}$ Tracey Shelton, Menstruation Huts still Widespread in Nepal, Despite Being Outlawed, ABC PREMIUM News (10 Dec. 2019); Gloria Steinem, Outrageous Acts AND Everyday Rebellions 366-69 (1986) (referring to menstruation huts as a means of excluding and subordinating women).

${ }^{49}$ Cf. Gillian Lester, A Defense of Paid Family Leave, 28 HARV. J.L. \& GENDER 1, 10-11, 23-24, 49-50, 79 (2005) (discussing fear of stereotypes in the context of maternity leave); See also Johnson, supra note 17, at 62.

${ }^{50}$ See e.g., Craig v. Boren, 429 U.S. 190 (1976).

${ }^{51}$ Inbal Cicurrel \& Rachel Sharaby, Women in Menstruation Huts, Variations in Preserving Purification Customs among Ethiopian Immigrants, 23 Journal Fem, St. in Religion 69, 78, 81-84 (2007).
} 
ways (as men always have) - we must demand supportive recognition of biological difference and yet, at other times, decry differentiation as discrimination. ${ }^{52}$ Any other perspective effectively accepts discrimination based on the fear of further subordination.

\section{Conclusion: From Privacy to Publicity}

All four faces of menstruation are valid and important - none should be downplayed or dismissed but instead considered as different aspects of the lived experience of womanhood. Beyond dichotomous negative and positive accounts of menstruation, the ways laws can subordinate or empower, objectify or reify, these faces are more complex than any single approach to femininity. The multiplicity of the lived experience of menstruation must be reflected in the multiplicity of meanings attributed to it. ${ }^{53}$ Ultimately, women must sculpt their own narratives of menstruation based on this range of meaning. There is no one way to empower women in the context of menstruation and beyond because women are complex and femininity is variable. Therefore, in promoting justice, the law must take a variety of approaches, flexing nimbly based on a woman's situation and individualized identity.

Moreover, the way women are different from each other and from men cannot be hidden, neatly tucked away. Despite its beneficial attributes, "privacy" has been abused in the ways it keeps certain aspects of femininity, from breastfeeding to domestic abuse, out of the public eye, hiding our difference as though it is inappropriate or worse, shameful. Jewish law has also suggested that women's glory lies within - in the private sphere. ${ }^{54}$ This conference reveals the blood, and its power, and ensures that women are not shielded from the public eye - our glory is both within, and without.

\footnotetext{
${ }^{52}$ Catherine Mackinnon, Feminism Unmodified: Discourses in Life and Law 37, 39 (1987) (“[D]emands for equality will always appear to be asking to have it both ways: the same when we are the same, different when we are different.").

${ }^{53}$ Hartman \& Marmon, supra note 21, at 392.

54 “All the Glory of the King's Daughter is Within.” Psalms 45:14; Bava Metzia 87a (BABYLONIAN TaLmUd) (explaining that Sarah's virtue was in remining inside and establishing the household).
} 